$1-1-1984$

\title{
Effect of place of residence on consumer attitudes concerning fresh produce marketed through direct farm markets in West Virginia
}

Robert L. Jack

Kitty Lou Blackburn

Follow this and additional works at: https://researchrepository.wvu.edu/ wv_agricultural_and_forestry_experiment_station_bulletins

\section{Digital Commons Citation}

Jack, Robert L. and Blackburn, Kitty Lou, "Effect of place of residence on consumer attitudes concerning fresh produce marketed through direct farm markets in West Virginia" (1984). West Virginia Agricultural and Forestry Experiment Station Bulletins. 685.

https://researchrepository.wvu.edu/wv_agricultural_and_forestry_experiment_station_bulletins/579 @ WVU. It has been accepted for inclusion in West Virginia Agricultural and Forestry Experiment Station Bulletins by an authorized administrator of

The Research Repository @ WVU. For more information, please contact ian.harmon@mail.wvu.edu. 


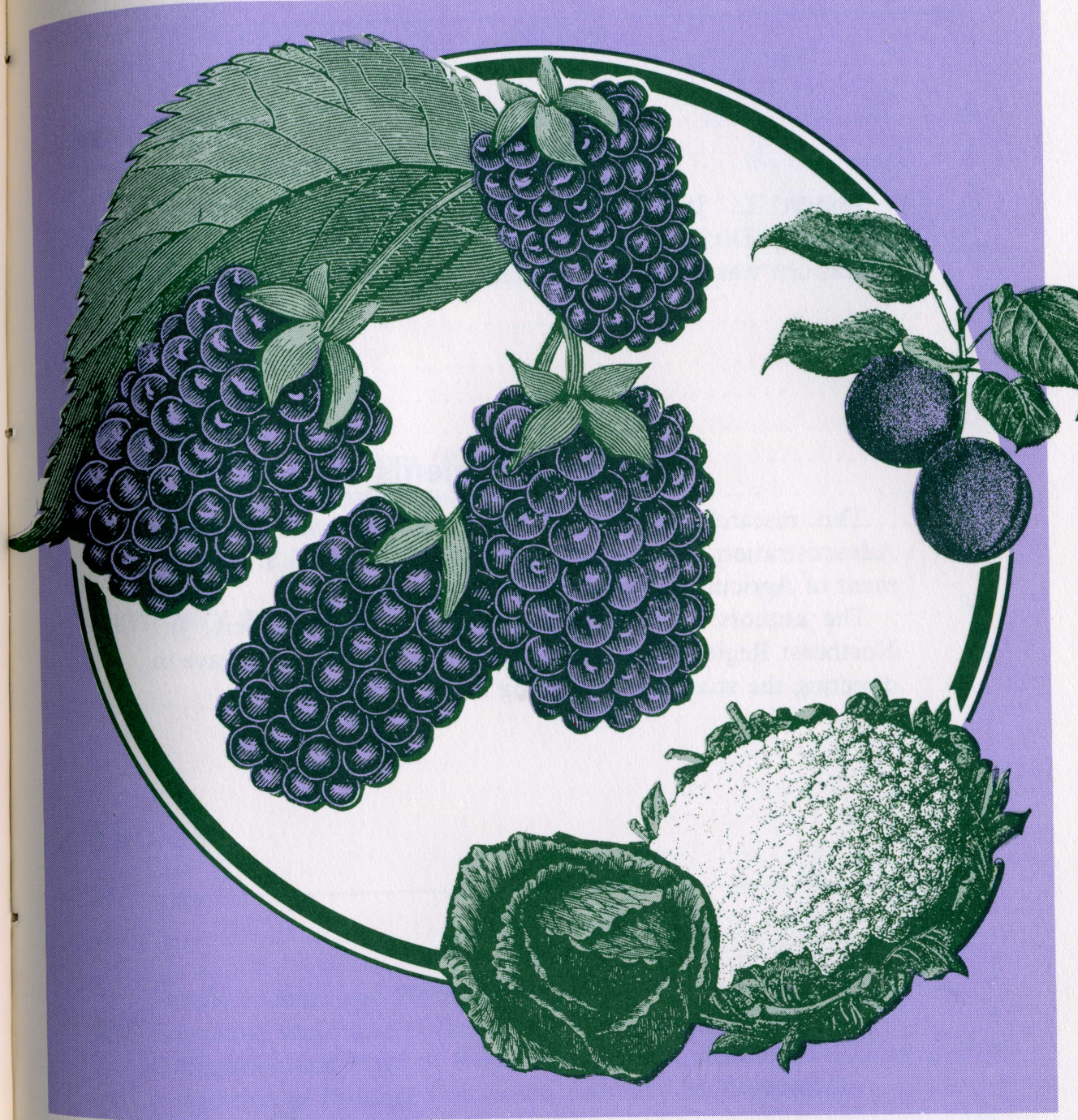

EFFECT OF PLACE OF RESIDENCE ON CONSUMER ATTITUDES CONCERNING FRESH PRODUCE MARKETED

THROUGH DIRECT FARM MARKETS IN WEST VIRGINIA 


\section{Contents}

\section{Authors}

Robertt L. Jack is agricultural economist and interim chairman, Division of Resource Management; Kitty Lou Blackbur:n was a graduate assistant in agricultural economics.

\section{Acknowledgments}

This research was funded by the Science and Education Administtration, Agricultural Research Service, U.S. Department of Agriculture, Washington, D.C.

The aluthors appreciated the help Howard W. Kerr, Jr., Northeasit Regional Director of Small Farms Research, gave in directing the study and designing the questionnaire.

WEST VIRGINIA UNIVERSITY

AGRICULTCURAL AND FORESTRY EXPERIMENT STATION COLILEGE OF AGRICULTURE AND FORESTRY

DALE W. ZINN, DIRECTOR MORGANTOWN

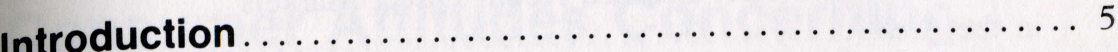

Purpose of Study ............................... 5

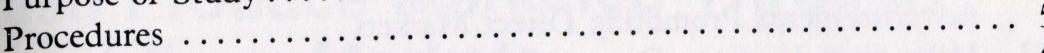

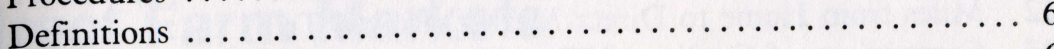

Characteristics of Sample $\ldots \ldots \ldots \ldots \ldots \ldots \ldots \ldots \ldots, 6$

Analysis ...................................... 10

Source of Produce ............................... 10

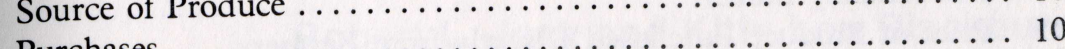

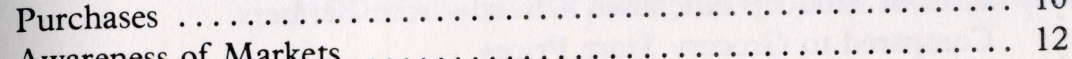

Awareness of Markets.

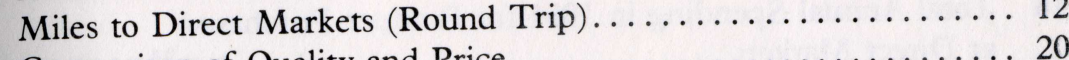

Comparison of Quality and Price $\ldots \ldots \ldots \ldots \ldots \ldots \ldots \ldots \ldots .20$

Expenditures for Produce........................... 20

Important Factors .................................. 24

Summary and Conclusions $\ldots \ldots \ldots \ldots \ldots \ldots \ldots \ldots . \ldots \ldots$

\section{Tables}

1 Family Income and Place of Residence of Consumers, $1981 \ldots \ldots 7$

2 Education and Place of Residence of Consumers, $1981 \ldots \ldots \ldots$. . 8

3 Occupation and Place of Residence of Consumers, 1981 ....... 9

4 Proportion of Produce Consumed Annually by Consumers that Is Produced in Own Garden..................... 11

5 Proportion of Produce Consumed Annually by Consumers that Came from Gardens of Friends or Neighbors .......... 11

6 Proportion of Consumers that Usually Process Fruits and Vegetables for Home Use ....................... 12

7 Proportion of Consumers Who Indicated the Number of Different Kinds of Fresh Fruits and Vegetables Purchased Weekly. 
8 Proportion of Produce Consumed Annually by Consumers that Is Purchased at Retail Stores.

9 Proportion of Produce Consumed Annually by Consumers that Is Purchased at Direct Markets

10 How Consumers First Learned About Direct Markets in the Area

11 Proportion of Consumers Who Had Seen or Heard Advertisements Promoting Direct Markets.

13 Comparison of Quality of West Vir (Round Trip) .......... 18 Virginia Produce with Quality of Produce Grown Out-of-State

4 Quality Rating of Produce Purchased at Direct Markets and Grocery Stores.

15 Price of Produce Purchased Directly from Farmers Compared to Grocery Store Prices ................... 21

16 Total Annual Spending in 1981 for Produce Purchased at Direct Markets .

17 Average Expenditures per Visit at Direct Markets by Different Types of Residences in West Virginia...

Weekly Expenditures for Produce by Season of Year ......... 25 Importance of Selected Characteristics When

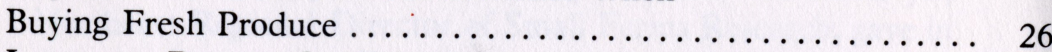

20 Important Reasons for Shopping at Direct Markets . . . . . . . 27

21 Reasons for Nonuse or Dislike of Direct Markets ........... 30

22 Suggested Changes Farmers Could Make that Would Increase Use of Direct Markets . ................ 31

23 Days Preferred for Direct Markets to Be Open for Business ..... 33

24 Time of Day Preferred for Direct Markets to Be Open for Business.

\section{Effect of Place of Residence on Consumer Attitudes Concerning Fresh Produce Marketed Through Direct Farm Markets In West Virginia}

\section{Robert L. Jack and Kitty Lou Blackburn}

\section{Introduction}

Direct marketing of fresh produce, an old concept, has taken on renewed interest in recent years. High retail food prices, concern for family health, and food quality are some of the reasons for this renewed interest by consumers.

Often producers are uncertain as to what consumers want in direct markets and consumers are uncertain as to what direct markets have to offer. Most of the research data on the topic are out of date.

In this study an attempt was made to examine relationships between place of residency (independent variable) and consumer attitudes, use, knowledge, purchase habits, and spending patterns (dependent variables). The findings should help improve direct marketing for the benefit of both producer and consumer.

\section{Purpose of Study}

1. To identify West Virginia consumer views concerning direct markets.

2. To determine consumer expectations and needs that must be satisfied to make direct markets successful.

3. To make recommendations for improving direct markets in West Virginia through the information obtained.

\section{Procedures}

Questionnaires were mailed to a sample of 5,000 West Virginia consumers randomly selected from telephone directories at the Morgantown office of the C \& P Telephone Co., and included all West Virginia cities. 
The first mailing of questionnaires with introductory letter was made during the week of November 16, 1981. A second mailing to the same addresses was made during the week of January 11,1982, and included a second questionnaire and follow-up letter. There were 821 (16.42 percent) usable questionnaires returned.

\section{Definitions}

In this survey, four types of direct marketing outlets were defined as:

1. Tailgate markets-produce is sold from a parked vehicle.

2. Roadside stands-produce is sold from some type of permanent structure usually located beside a highway.

3. Farmers' markets-producers sell their produce at one central location. These markets may be sponsored by city, county, or state government or they may be operated independently.

4. Pick-your-own operations (PYO)-consumers harvest their own produce at the farm.

Rural, non-farm, and farm are areas outside cities, towns, and suburbs.

\section{Characteristics of Sample}

More than 55 percent of the West Virginia respondents reported annual household income of $\$ 15,000$ to $\$ 39,000$. Only 6.8 percent reported less than $\$ 5,000$, while slightly more than 8 percent had incomes of $\$ 40,000$ or more per year (Table 1). None of the farm respondents reported an annual family income of more than $\$ 40,000$.

Place of residence data show a higher percentage of respondents located in city, suburban, and town areas than expected in West Virginia. This may have occurred because of the procedure used in selecting the sample, only people with telephone service. More than 73 percent of the respondents lived in city, suburban, and town areas. Only 6.4 percent lived on a farm (Table 1).

More than 78 percent of the respondents had completed 9 to 16 years of schooling. As the place of residency became more rural, fewer years of schooling were reported (Table 2). Only 8.4 percent of the sample completed $0-8$ years, while more than 13 percent had schooling beyond the four-year college degree.

The highest percentage of respondents, retired/disabled (23.8), lived mostly in the city and town areas. Next in importance was homemakers living in suburban and rural, non-farm areas (Table 3). The proportion of laborers living in rural, non-farm and farm areas was more than double those living in other areas.

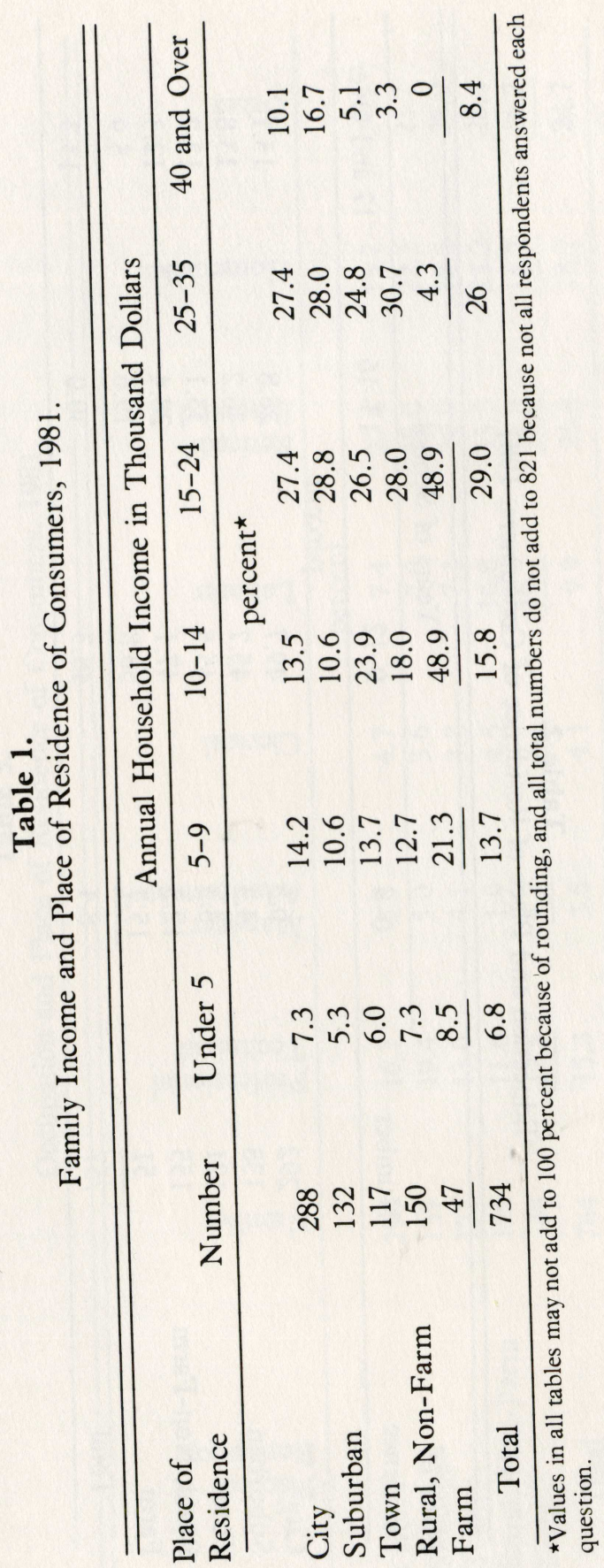




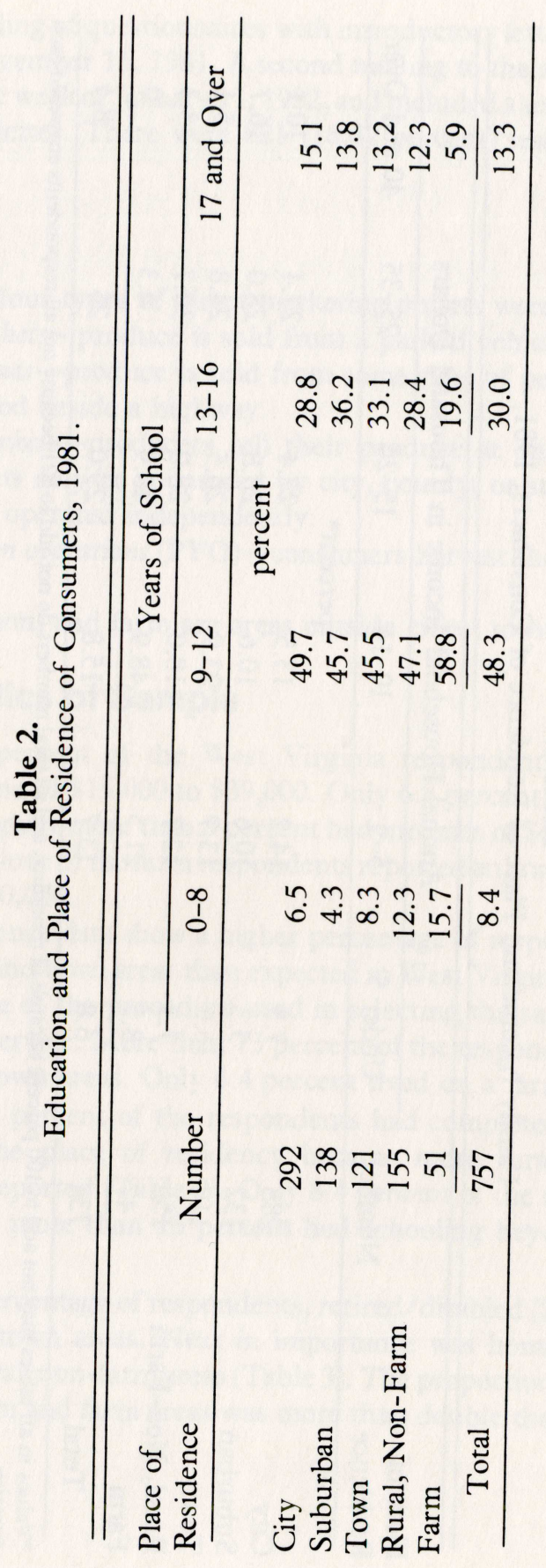

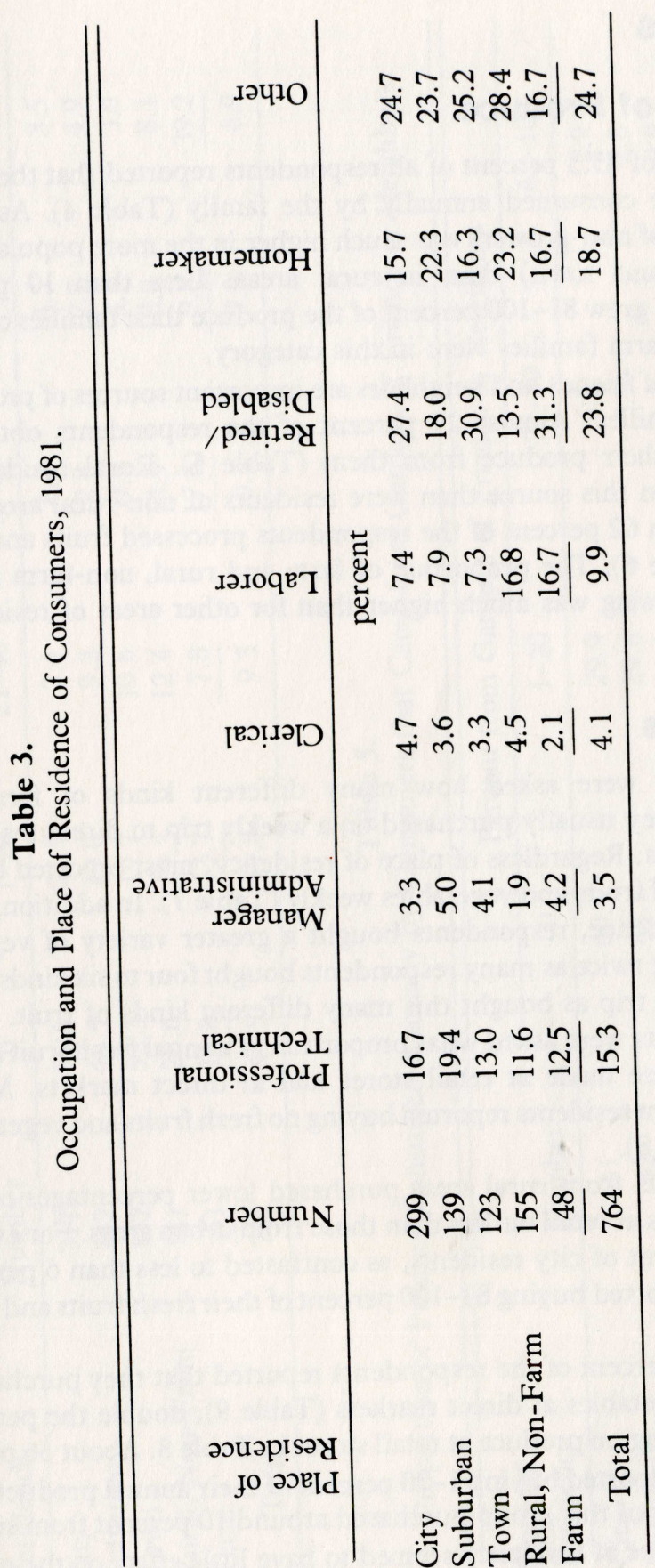




\section{Analysis}

\section{Sources of Produce}

An average of 45.5 percent of all respondents reported that they grew none of the produce consumed annually by the family (Table 4 ). As expected, the percentage of non-growers was much higher in the more populated areas (city, suburban, and town) than in rural areas. Less than 10 percent of the respondents grew 81-100 percent of the produce their families consumed; 39.2 percent of farm families were in this category.

Gardens of friends and neighbors are important sources of produce for West Virginia families. Almost 29 percent of the respondents obtained 1 to 20 percent of their produce from them (Table 5). Rural residents were less dependent on this source than were residents of non-rural areas.

More than 62 percent of the respondents processed fruits and vegetables at home (Table 6). The proportion of farm and rural, non-farm families doing home processing was much higher than for other areas of residency.

\section{Purchases}

Respondents were asked how many different kinds of fresh fruits and vegetables they usually purchased on a weekly trip to direct markets or retail grocery stores. Regardless of place of residency, most reported buying one to three kinds of fruits and vegetables weekly (Table 7). In addition, regardless of place of residence, respondents bought a greater variety of vegetables than fruits. Almost twice as many respondents bought four to six kinds of vegetables per shopping trip as bought this many different kinds of fruit.

Respondents were asked what proportion of annual fresh fruit and vegetable purchases were made at retail stores and at direct markets. More than 43 percent of farm residents reported buying no fresh fruits and vegetables at retail stores (Table 8).

Respondents from rural areas purchased lower percentages of fresh fruits and vegetables at retail outlets than those from urban areas. For example, more than 31 percent of city residents, as contrasted to less than 6 percent of farm residents, reported buying $81-100$ percent of their fresh fruits and vegetables at retail stores.

About 46 percent of the respondents reported that they purchased no fresh fruits and vegetables at direct markets (Table 9), double the percentage that reported buying no produce at retail stores in Table 8 . About 36 percent of the respondents reported buying 1-20 percent of their annual produce from direct markets. Most of this group purchased around 10 percent from such markets. Rurality of place of residency seemed to have little effect on the proportion of

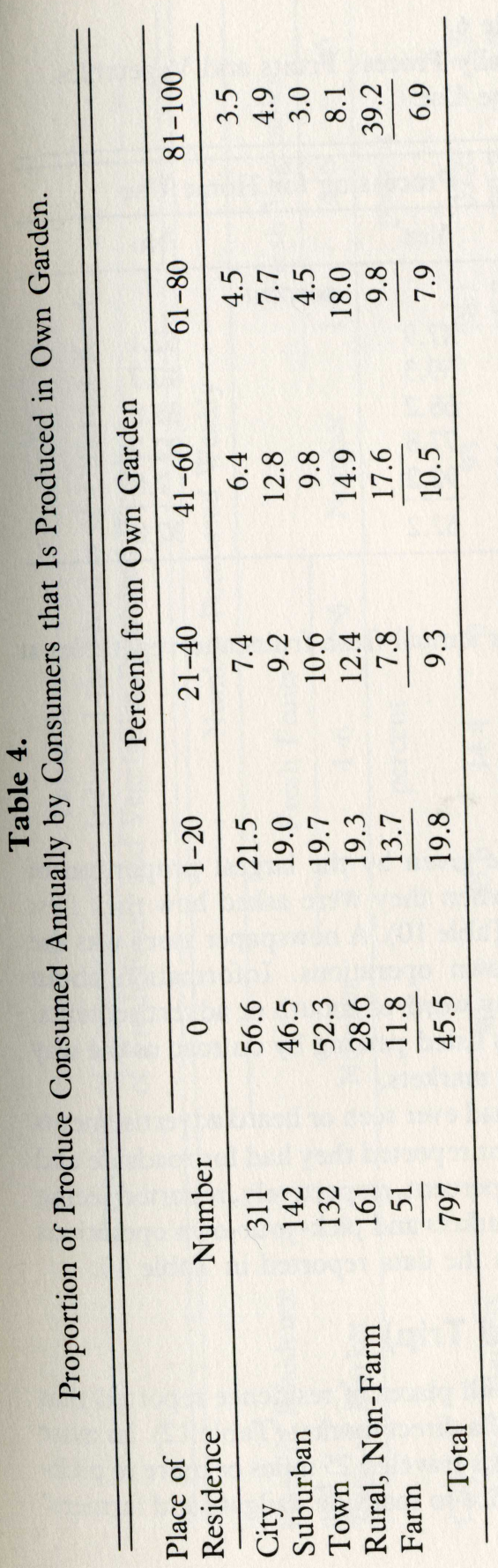

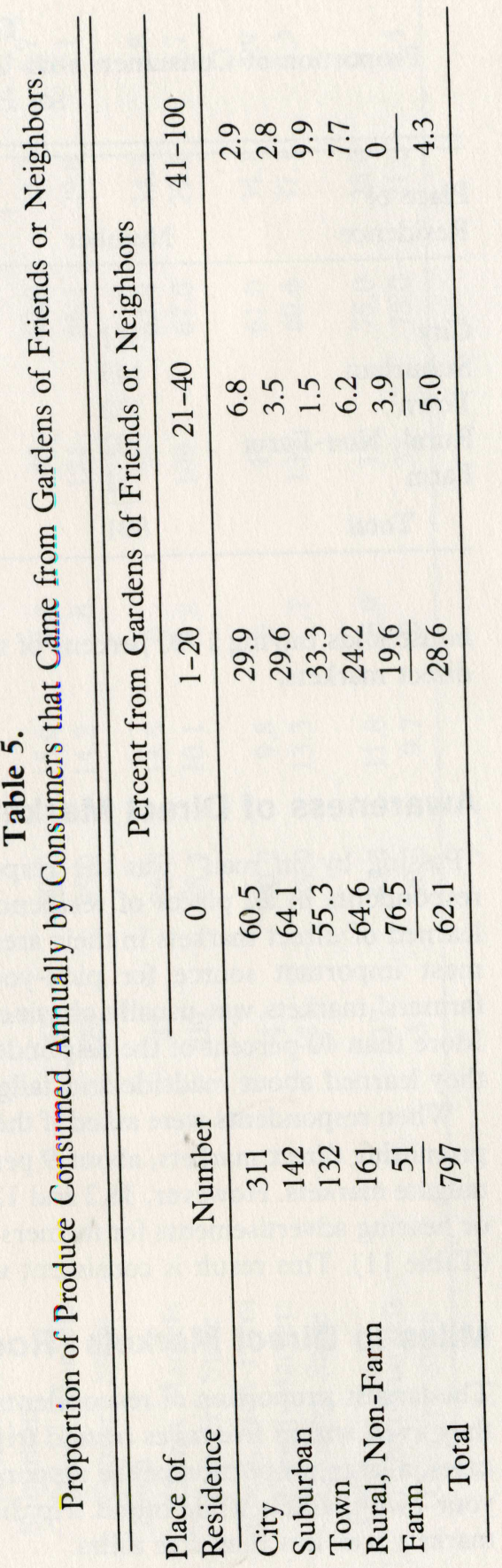


Table 6.

Proportion of Consumers that Usually Process Fruits and Vegetables for Home Use.

\begin{tabular}{lccc}
\hline \hline \multirow{2}{*}{$\begin{array}{l}\text { Place of } \\
\text { Residence }\end{array}$} & Number & \multicolumn{2}{l}{ Processing for Home Use } \\
\cline { 3 - 4 } & & Yes & No \\
\hline City & 311 & & percent \\
Suburban & 145 & 47.9 & 52.1 \\
Town & 132 & 59.3 & 40.7 \\
Rural, Non-Farm & 162 & 68.2 & 31.8 \\
Farm & 51 & 77.8 & 22.2 \\
\multicolumn{1}{c}{ Total } & $\mathbf{8 0 1}$ & $\underline{92.2}$ & $\underline{7.8}$ \\
\hline
\end{tabular}

households buying 1-20 percent of their annual fresh fruits and vegetables at direct markets.

\section{Awareness of Direct Markets}

"Passing by on road" was the response given by the largest proportion of respondents in all places of residency when they were asked how they first learned of direct markets in their area (Table 10). A newspaper story was the most important source for pick-your-own operations. Information about farmers' markets was usually obtained by word-of-mouth or advertisements. More than 40 percent of the respondents listed passing by on road as the way they learned about roadside and tailgate markets.

When respondents were asked if they had ever seen or heard advertisements promoting direct markets, about 9 percent reported they had for roadside and tailgate markets. However, 36.2 and 12.3 percent, respectively, reported seeing or hearing advertisements for farmers' markets and pick-your-own operations (Table 11). This result is consistent with the data reported in Table 10.

\section{Miles to Direct Markets (Round Trip)}

The largest proportion of respondents in all places of residence reported that they lived within five miles (round trip) of a direct market (Table 12). In most cases, a large proportion of the respondents traveled 25 miles or more to pickyour-own markets while round trip distance to roadside, tailgate and farmers'
markets was less than five miles.

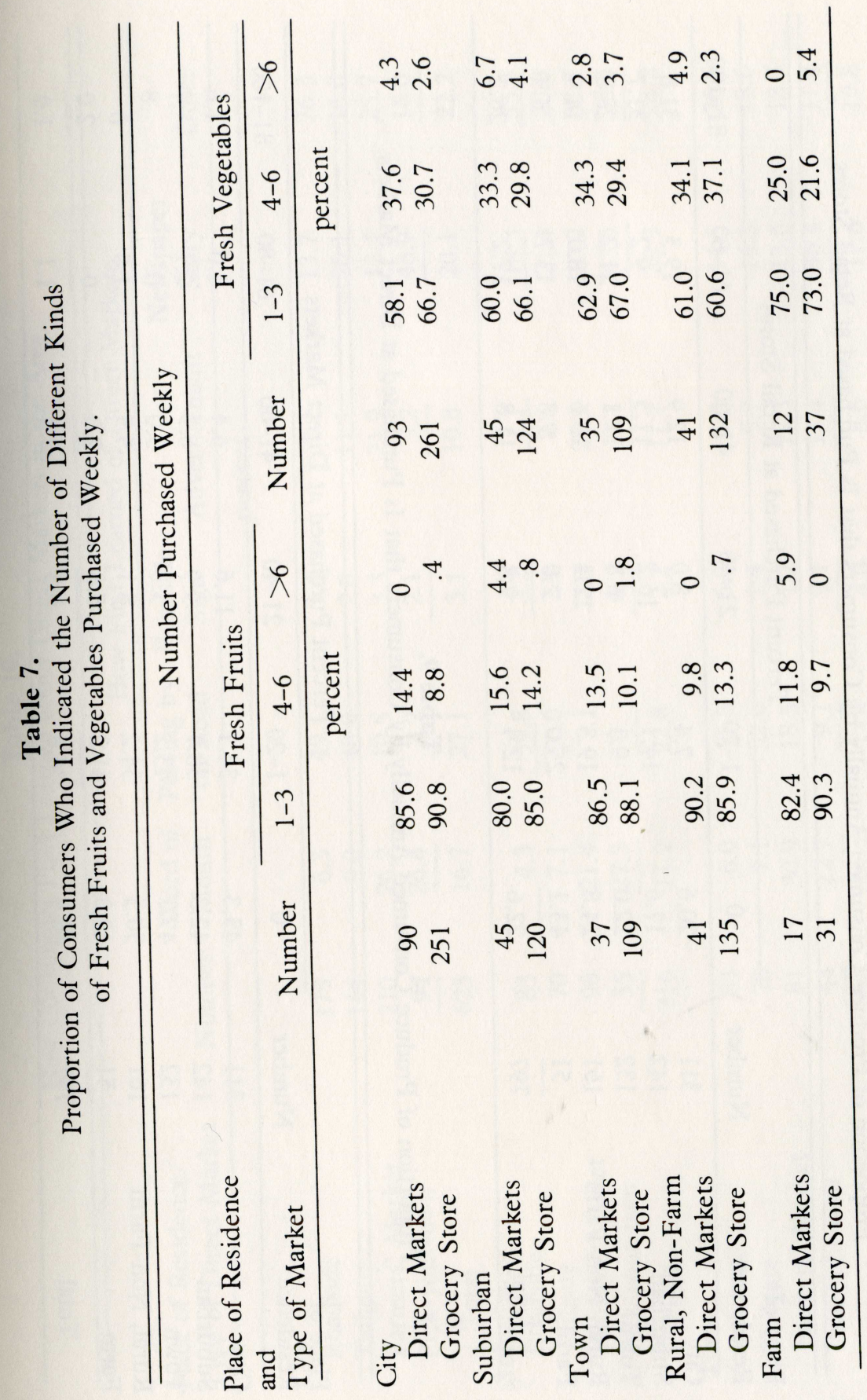

13 

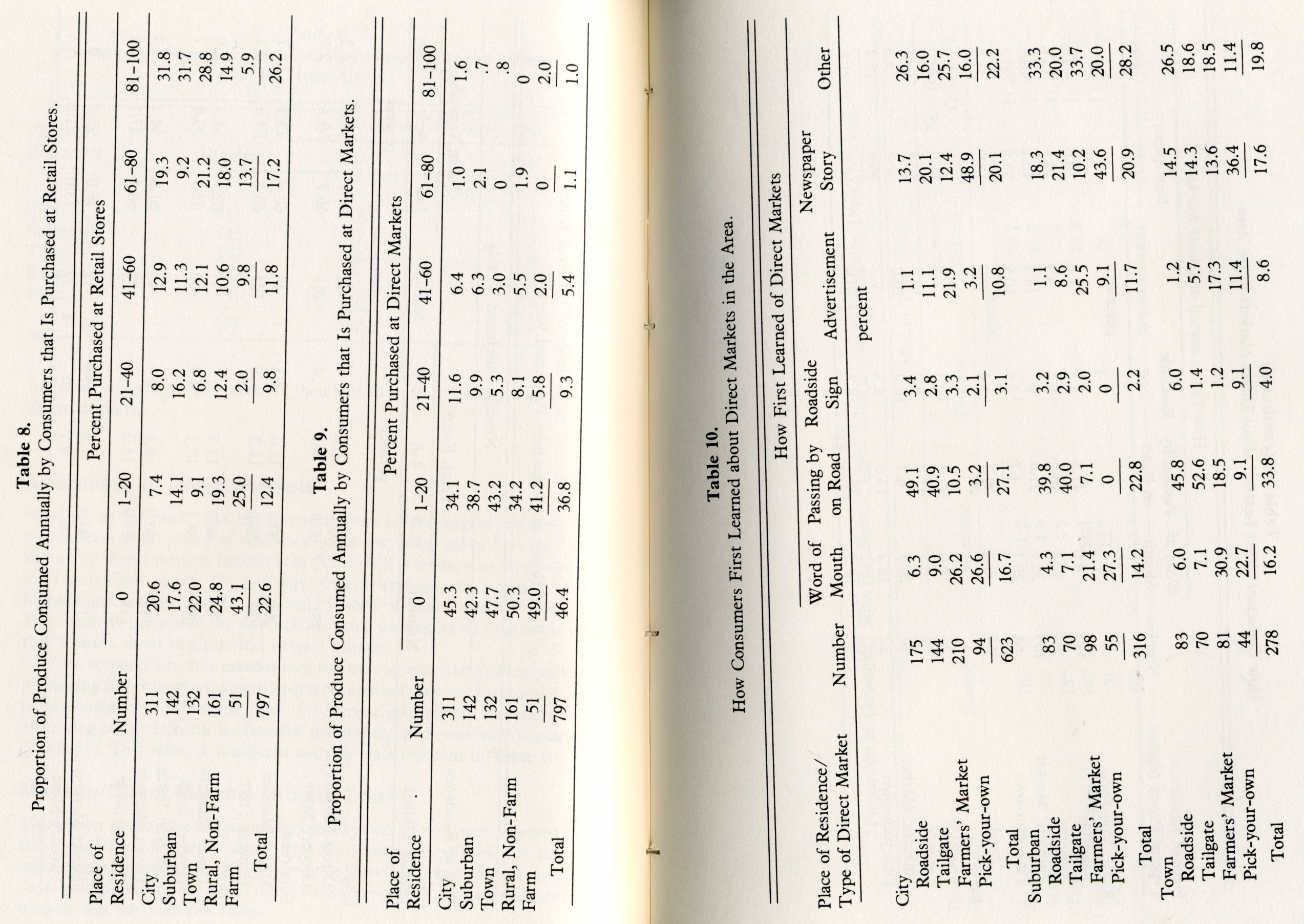

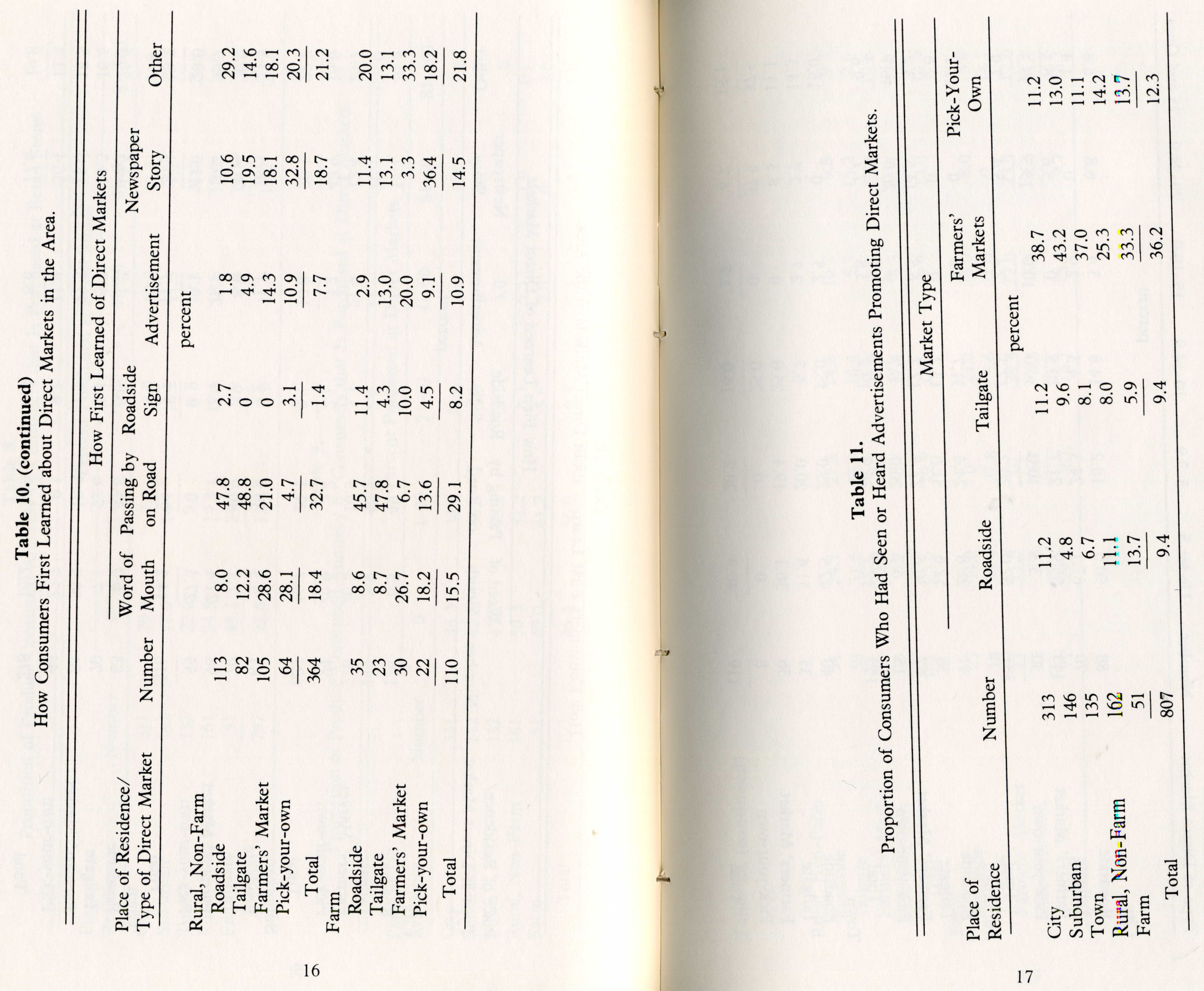


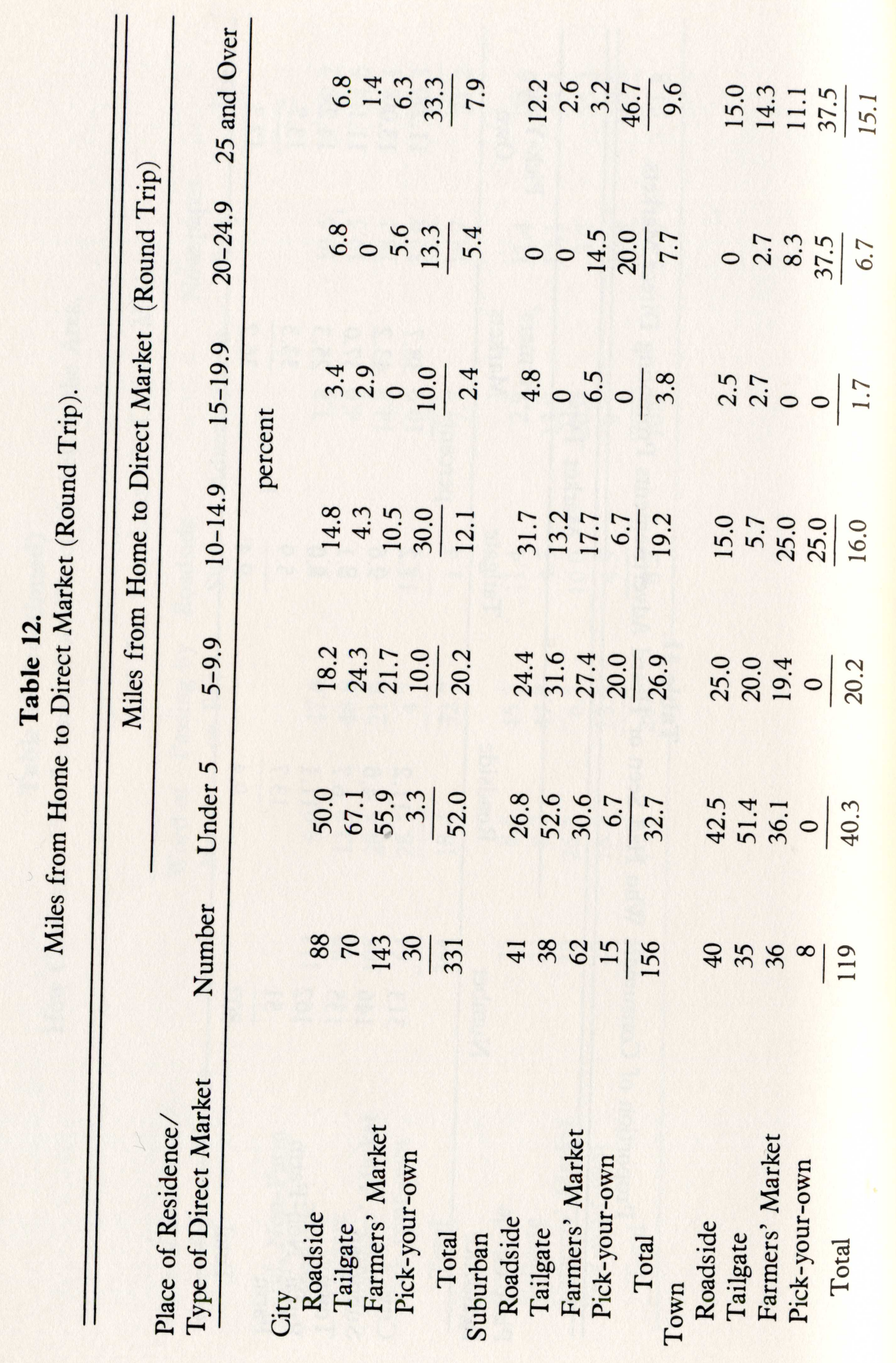

åc

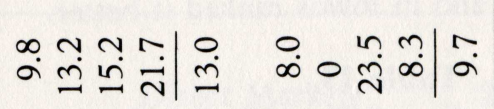

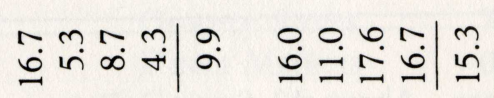

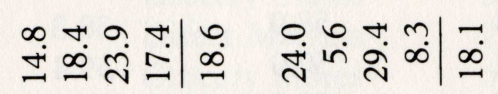

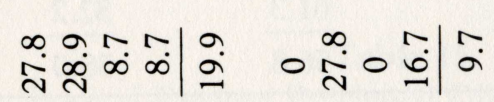

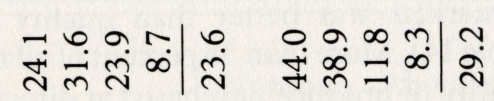

แี่

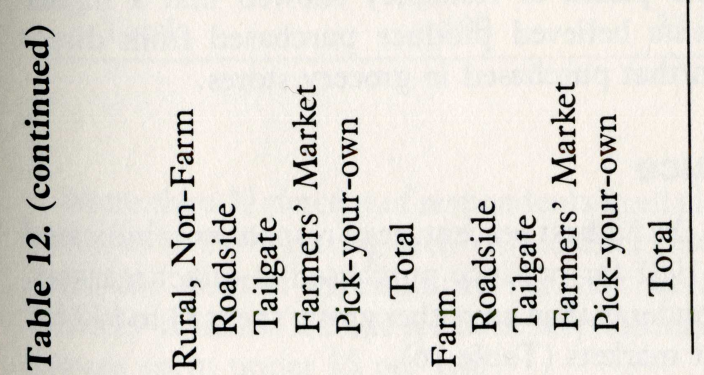




\section{Comparison of Quality and Price}

Regardless of where they lived, more than half of the respondents believed the quality of fruit and vegetables produced in West Virginia was about the same as the quality of produce grown outside the state (Table 13). Although 38 percent of all respondents ranked West Virginia produce as better, a lower percentage of respondents living on farms and in towns ranked it better.

Table 13.

Comparison of Quality of West Virginia Produce with Quality of Produce Grown Out-of-State.

\begin{tabular}{lcccr}
\hline \hline $\begin{array}{l}\text { Place of } \\
\text { Residence }\end{array}$ & Number & About the Same & Better & Worse \\
\hline & & \multicolumn{3}{c}{ percent } \\
City & 214 & 58.9 & 38.3 & 2.8 \\
Suburban & 104 & 50.0 & 39.4 & 10.6 \\
Town & 92 & 59.8 & 33.7 & 6.5 \\
Rural, Non-Farm & 98 & 55.1 & 41.8 & 3.1 \\
Farm & 31 & $\underline{61.3}$ & $\underline{32.2}$ & $\underline{6.5}$ \\
\multicolumn{1}{c}{ Total } & 539 & 56.8 & 38.0 & 5.2 \\
\hline
\end{tabular}

Respondents, regardless of place of residency, believed that the quality of produce purchased at direct markets was better than quality of produce purchased at grocery stores (Table 14). More than 38 percent of all respondents in all residencies ranked the quality of produce purchased at direct markets as excellent, while only about 5 percent ranked grocery store produce this high Only a low percentage ranked produce purchased from direct markets or grocery stores as poor.

About 60 percent of all respondents believed produce purchased directly from the farmer was priced lower than produce purchased in grocery stores (Table 15). Slightly more than 8 percent said farm produce was priced higher. The data from the more rural places of residency showed that a higher percentage of these respondents believed produce purchased from direct markets was lower priced than that purchased in grocery stores.

\section{Expenditures for Produce}

Regardless of where they lived, the highest percentage of respondents indicated they spent from $\$ 1$ to $\$ 50$ in 1981 for produce purchased at direct markets. A higher percentage farm respondents than any other group spent $\$ 1$ to $\$ 50$ for produce purchased from direct markets (Table 16).
Table 14.

Quality Rating of Produce Purchased at Direct Markets and Grocery Stores.

\begin{tabular}{llrrrr}
\hline \multirow{2}{*}{$\begin{array}{l}\text { Place of } \\
\text { Residence }\end{array}$} & \multicolumn{4}{c}{ Quality Rating } \\
\cline { 3 - 6 } & Source of Purchase & Poor & Fair & Good & Excellent \\
\hline \multirow{3}{*}{ City } & Direct Markets & 2.1 & 8.8 & 47.3 & 41.8 \\
& Grocery Stores & 2.9 & 38.6 & 51.1 & 7.5 \\
Suburban & Direct Markets & 0.9 & 4.4 & 55.8 & 39.9 \\
Town & Grocery Stores & 7.4 & 41.5 & 45.2 & 5.9 \\
& Direct Markets & 0 & 8.3 & 53.1 & 38.5 \\
Rural, Non-Farmyyyyyy & Grocery Stores & 4.8 & 44.8 & 45.6 & 4.8 \\
Farm & Direct Markets & 0.8 & 5.7 & 52.8 & 40.7 \\
& Grocery Stores & 8.7 & 47.3 & 40.0 & 4.0 \\
& Direct Markets & 2.6 & 5.3 & 50.0 & 42.1 \\
& Grocery Stores & 6.7 & 51.1 & 37.8 & 4.4 \\
\hline
\end{tabular}

Table 15.

Price of Produce Purchased Directly from Farmers Compared to Grocery Store Prices.

\begin{tabular}{lrrrr}
\hline \hline $\begin{array}{l}\text { Place of } \\
\text { Residence }\end{array}$ & Number & About the Same & Higher & Lower \\
\hline \multicolumn{4}{c}{ City } & \multicolumn{4}{c}{ percent } \\
Suburban & 203 & 38.9 & 10.3 & 50.8 \\
Town & 95 & 40.0 & 6.3 & 53.7 \\
Rural, Non-Farm & 72 & 25.0 & 9.7 & 65.3 \\
Farm & 94 & 25.5 & 5.3 & 69.2 \\
\multicolumn{1}{c}{ Total } & 35 & $\underline{20.0}$ & $\underline{8.6}$ & $\underline{71.4}$ \\
\hline
\end{tabular}

More than 39 percent of respondents in all places of residency indicated they spent $\$ 5$ to $\$ 9.99$ during each visit to direct farm markets (Table 17). In most cases the greatest expenditures per visit were made at pick-your-own and farmers' markets. Except for farm respondents, about 25 percent of the other groups spent under $\$ 5$ per visit. 

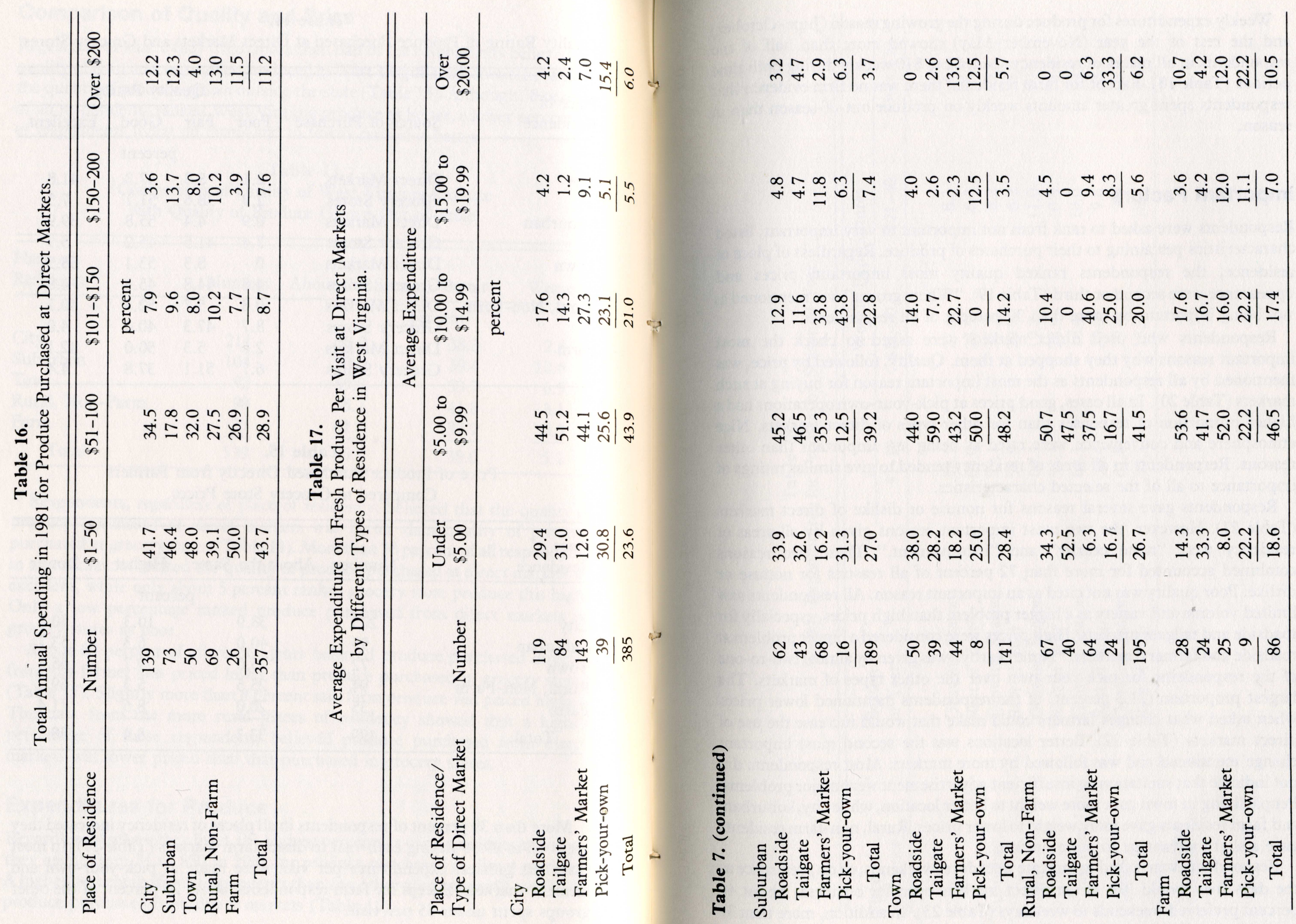
Weekly expenditures for produce during the growing season (June-October) and the rest of the year (November-May) showed more than half of the respondents in all places of residency spent $\$ 1$ to $\$ 10$ weekly during both time periods (Table 18). Except for farm residents, there was no firm evidence that respondents spent greater amounts weekly on produce out-of-season than in season.

\section{Important Factors}

Respondents were asked to rank from not important to very important, listed characteristics pertaining to their purchases of produce. Regardless of place of residence, the respondents ranked quality most important, prices and appearance were second or third (Table 19). "Where grown" was mentioned as not being important by more than 30 percent of all respondents.

Respondents who used direct markets were asked to check the most important reasons why they shopped at them. Quality, followed by price, was mentioned by all respondents as the most important reason for buying at such markets (Table 20). In all cases, good prices at pick-your-own operations had a higher proportion of responses than for other types of direct markets. Nice atmosphere and convenience were rated as being less important than other reasons. Respondents in all areas of residency tended to give similar ratings of importance to all of the selected characteristics.

Respondents gave several reasons for nonuse or dislike of direct markets (Table 21). However, the two most important reasons given by all areas of residency were "none nearby" and "inconvenient." These two reasons combined accounted for more than 72 percent of all reasons for nonuse or dislike. Poor quality was not cited as an important reason. All respondents saw limited volume and variety as a bigger problem than high prices, especially for roadside and tailgate markets. High prices were considered a bigger problem at roadside and farmers' markets. "None nearby" was given by almost two-to-one of the respondents for pick-your-own over the other types of markets. The largest proportion (21.3 percent) of the respondents mentioned lower prices when asked what changes farmers could make that would increase the use of direct markets (Table 22). Better locations was the second most important change mentioned and was followed by more markets. Most respondents did not indicate that sanitation or insufficient advertisement were major problems. People living in town gave more weight to better location, while city, suburban, and farm residents gave more weight to lower prices. Rural, non-farm residents gave a slight advantage to more markets.

Respondents were asked to indicate weekdays, weekends, or no preference as the days they would like to see direct markets open for business. About 40 percent preferred weekends to weekdays (Table 23). In addition, more than 37 percent stated no preference for days to be open for business. Farm

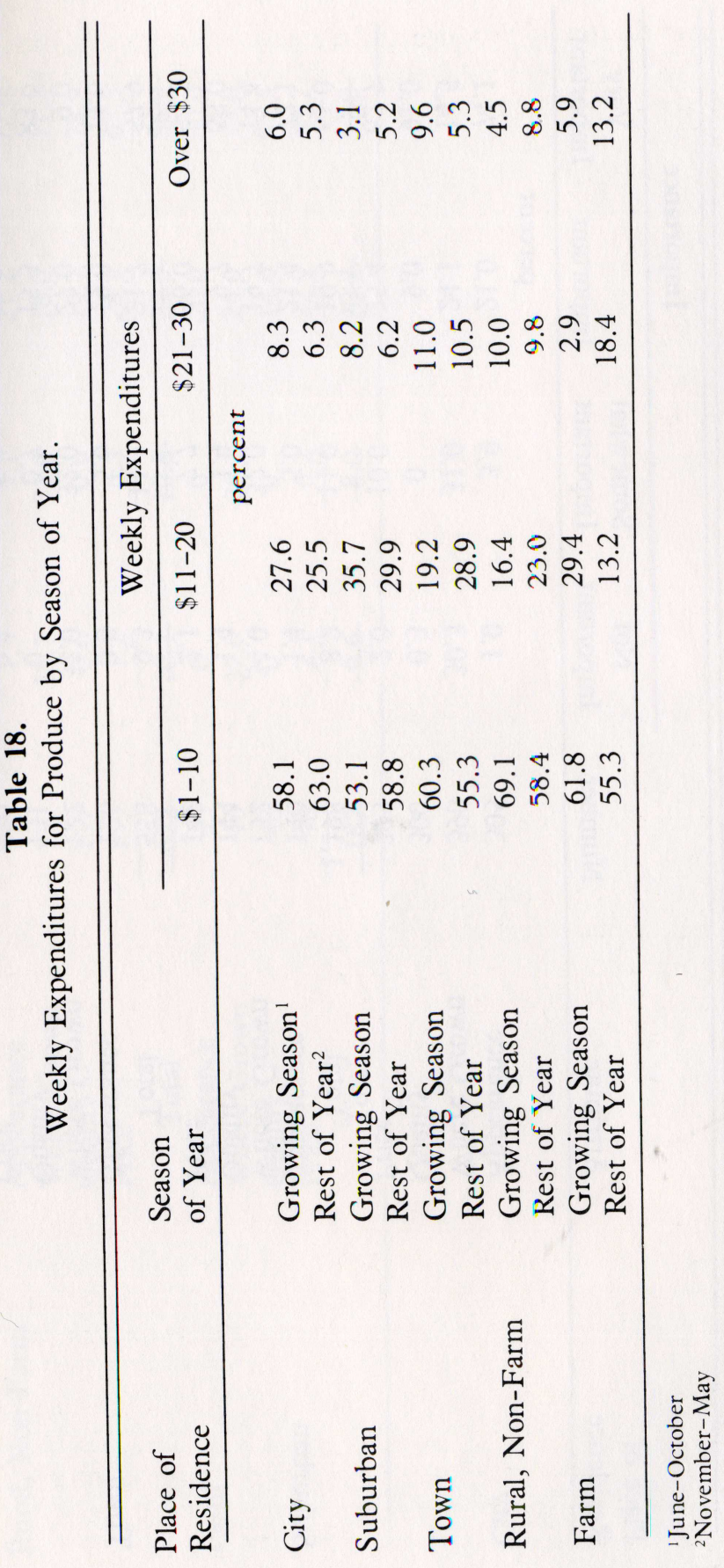




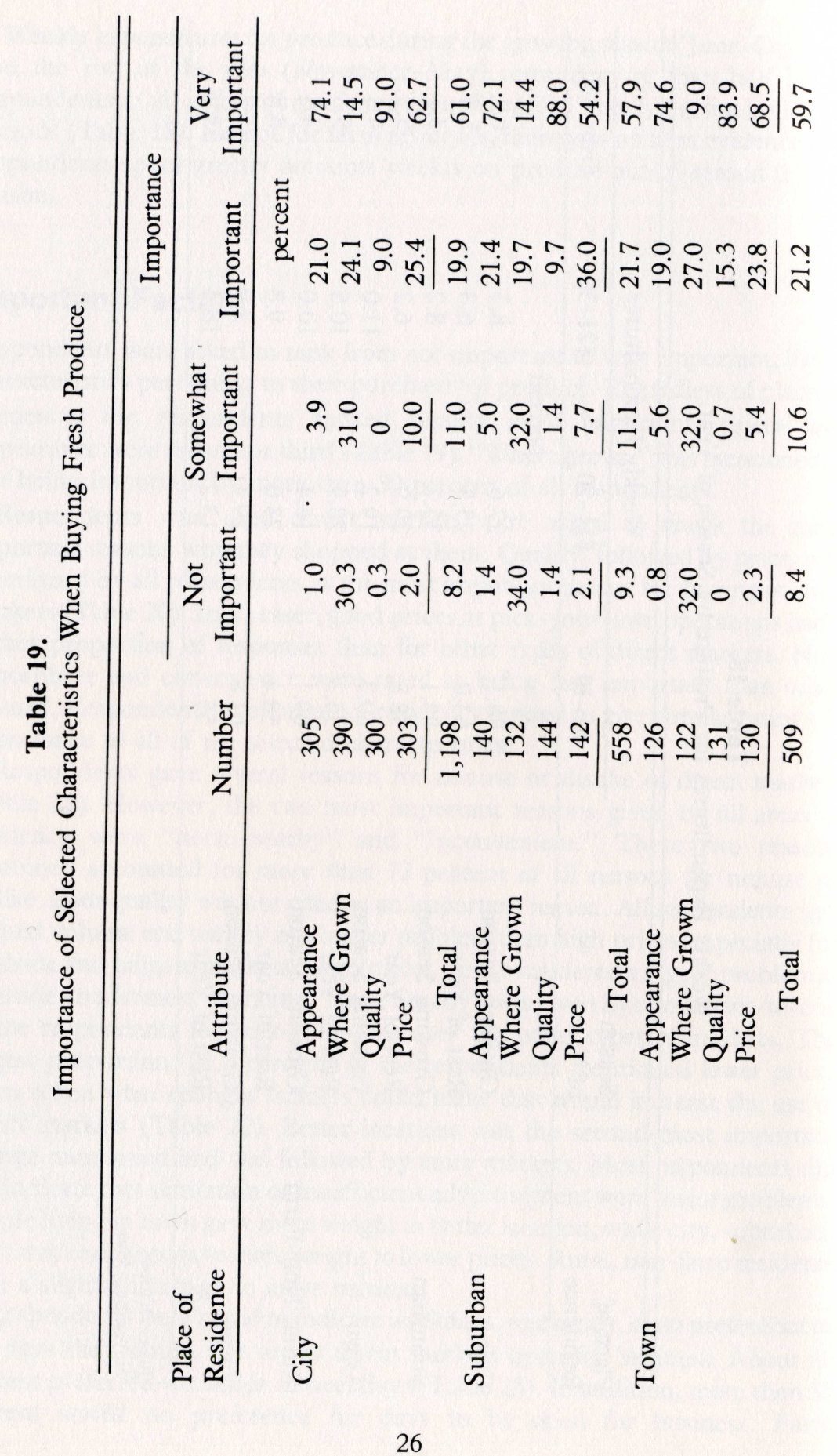

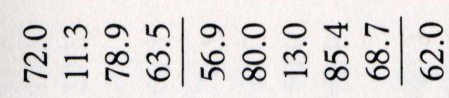

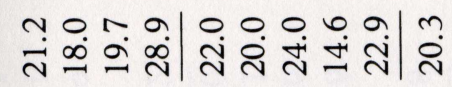

in

mîn

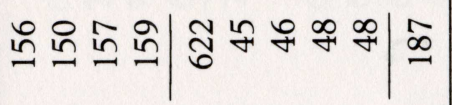

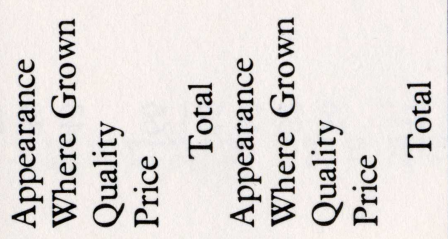

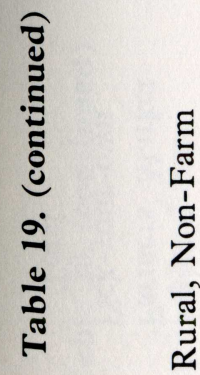

歪 


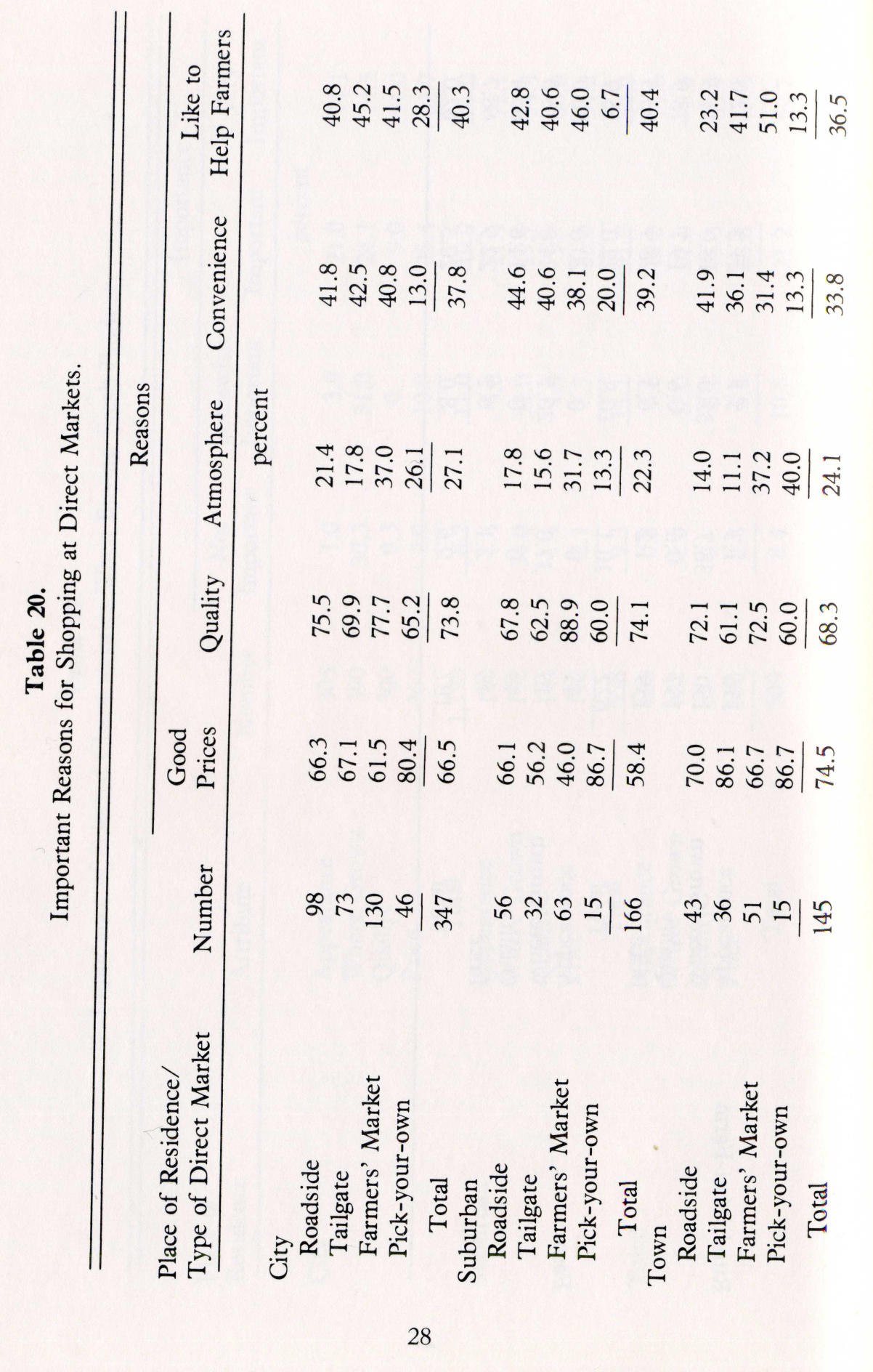

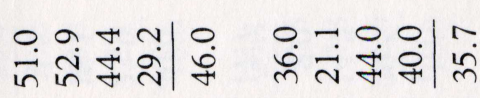

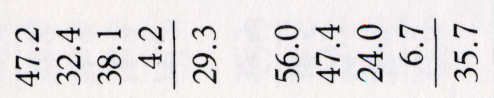

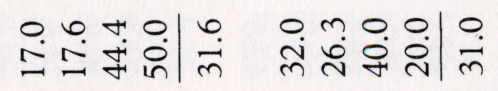

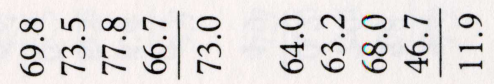

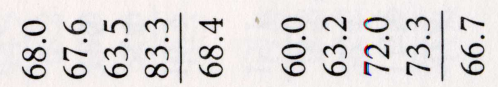

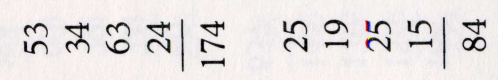

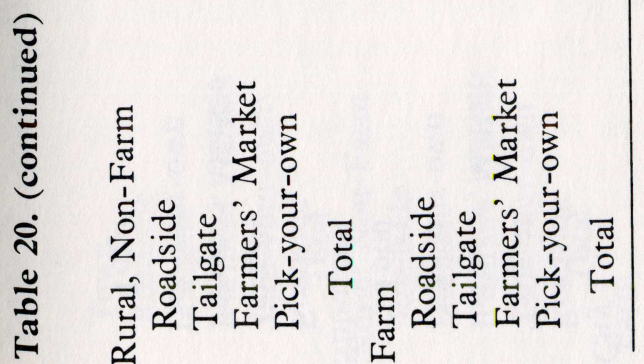




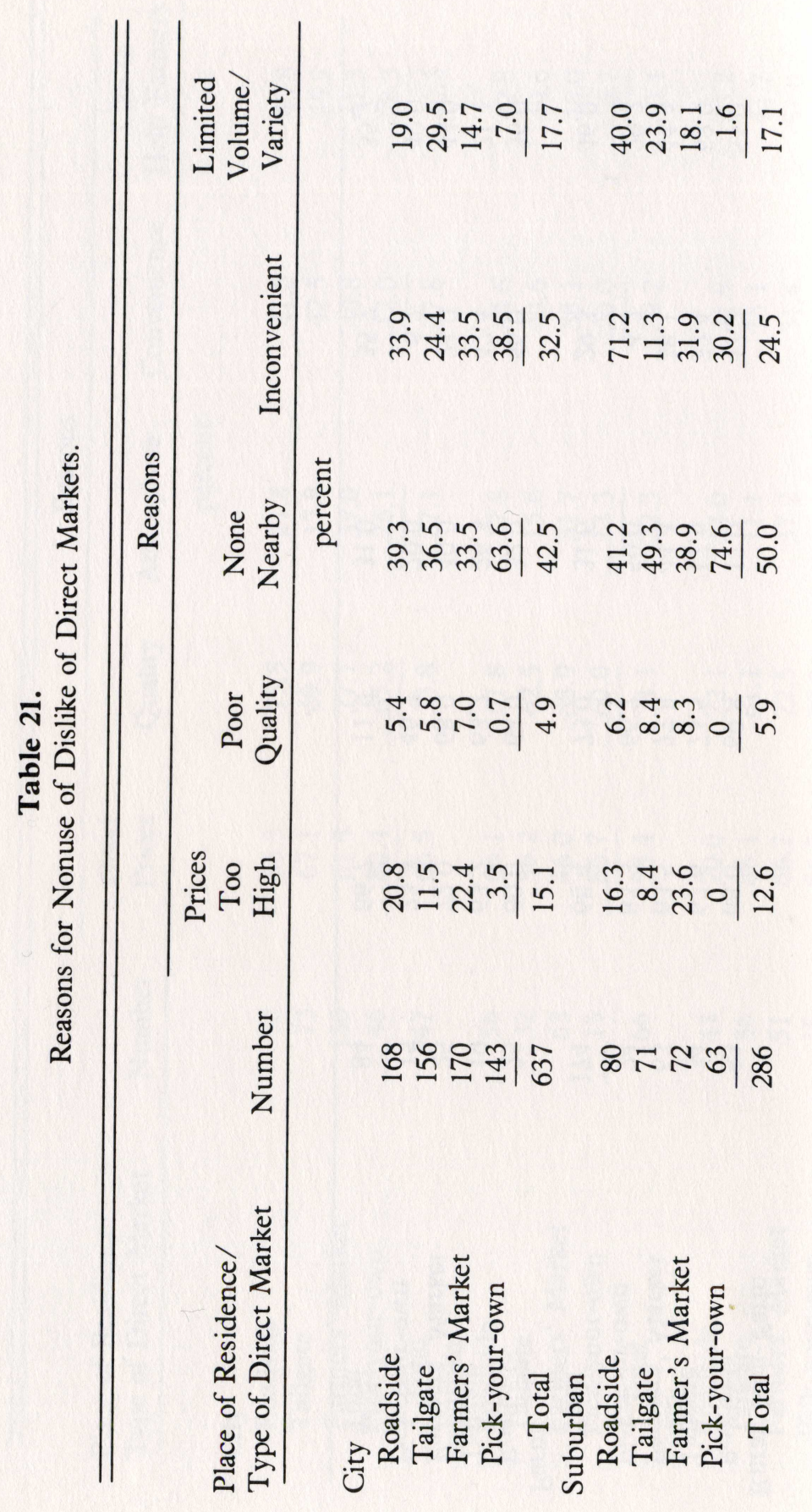

30

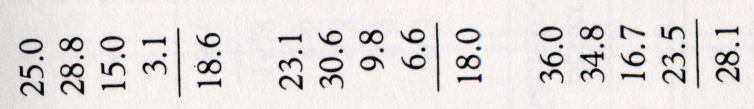

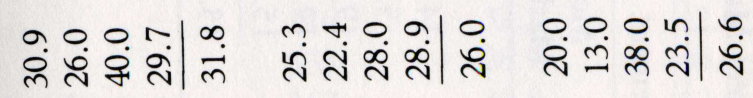

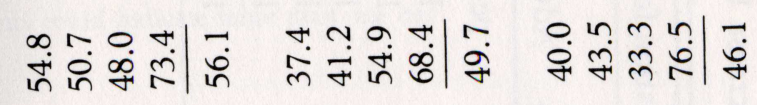

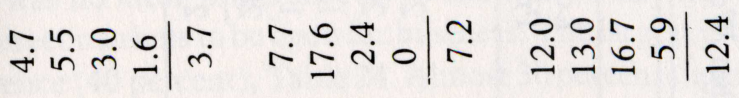

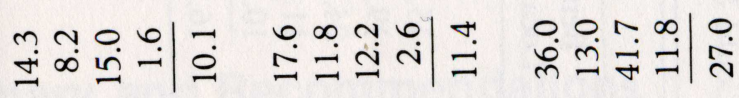

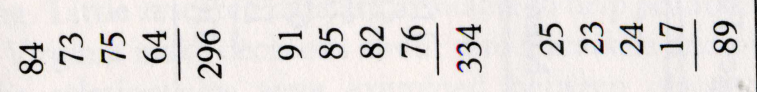

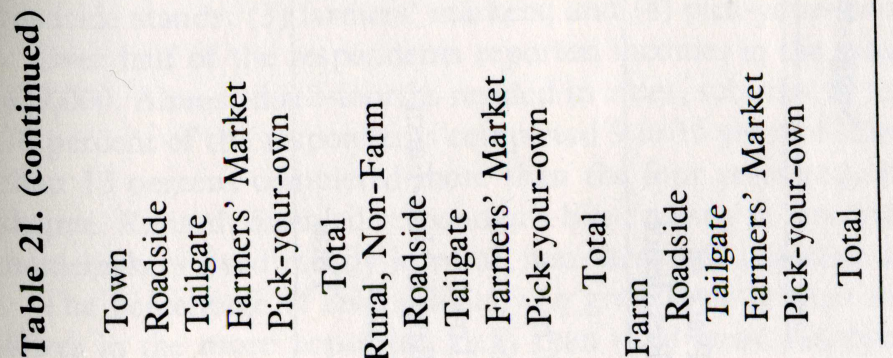




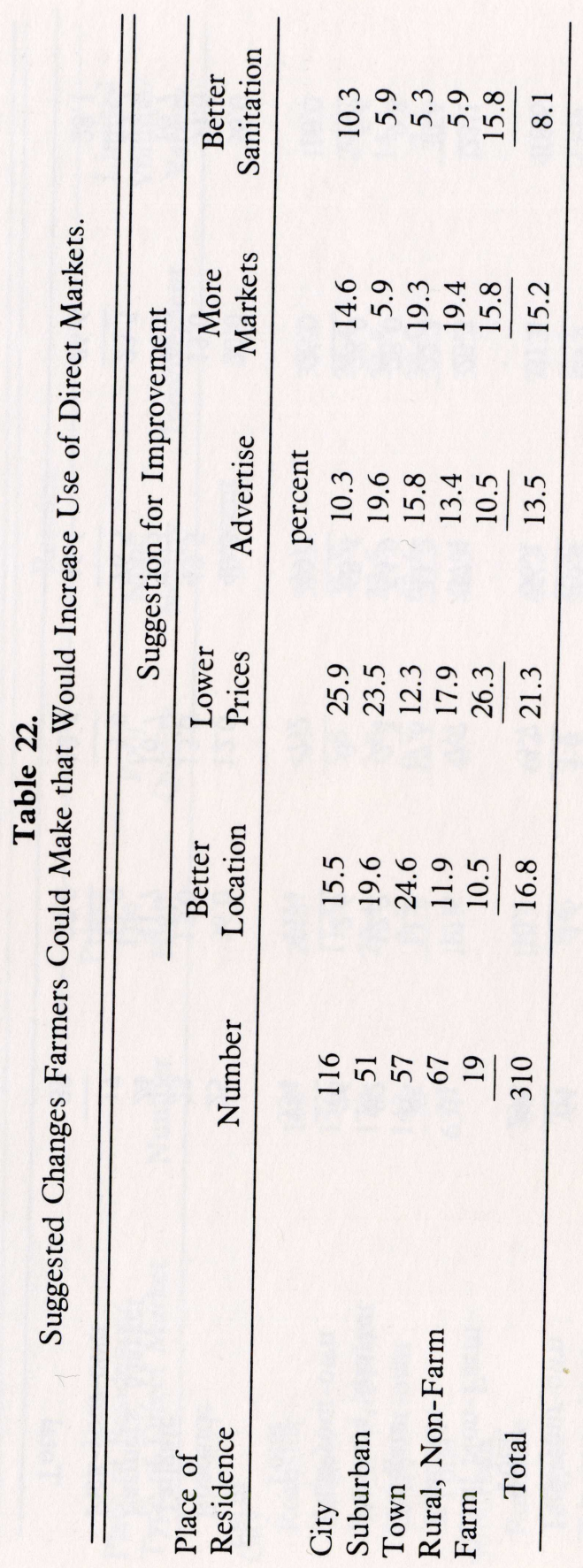

Table 23.

Days Preferred for Direct Markets to Be Open for Business.

\begin{tabular}{lcccc}
\hline $\begin{array}{l}\text { Place of } \\
\text { Residence }\end{array}$ & Number & Weekdays & Weekends & $\begin{array}{c}\text { No } \\
\text { Preference }\end{array}$ \\
\hline & & & percent & \\
City & 313 & 29.4 & 39.6 & 40.3 \\
Suburban & 146 & 32.2 & 42.4 & 34.9 \\
Town & 135 & 28.9 & 40.0 & 39.3 \\
Rural, Non-Farm & 162 & 35.8 & 42.6 & 33.3 \\
Farm & $\underline{51}$ & $\underline{23.5}$ & $\underline{29.4}$ & $\underline{\mathbf{5 1 . 0}}$ \\
\multicolumn{1}{c}{ Total } & $\mathbf{8 0 7}$ & $\mathbf{3 0 . 7}$ & 40.1 & 37.9 \\
\hline
\end{tabular}

Respondents could indicate more than one day

respondents had the largest proportion of no preference responses (51.0 percent).

There was no clear preference as to the time of day that total respondents wanted direct markets to be open for business. The largest proportion indicated no preference ( 40 percent), Table 24 .. Almost 30 percent suggested evenings, 24 percent wanted afternoons, and around 23 percent wanted morning hours of operation. Place of residency seemed to have little effect on hours preferred.

\section{Summary and Recommendations}

In recent years, the interest in direct marketing of fresh produce has been increasing. Little research data are available to help producers and consumers in West Virginia make decisions abrout direct markets and purchasing. In this study the relationships were examined between place of residency and consumer attitudes, use, knowledge, purchase habits, and spending habits. The four types of direct markets used in this study were (1) tailgate markets; (2) roadside stands; (3) farmers' markets; and (4) pick-your-own operations.

Over half of the respondents reported incomes in the range of $\$ 15,000$ to $\$ 39,000$. Almost three-fourths resided in cities, suburbs, or towns. More than 78 percent of the respondents completed 9 to 16 years of schooling and more than 13 percent completed more than the four years required for a college degree. Retired, disabled respondemts lived mostly in city and town areas and homemakers lived mostly in rural, non-farm and suburban areas.

The percentage of respondents who grew some of their own produce was lower in the more populated areas than rural areas. Gardens of friends and 


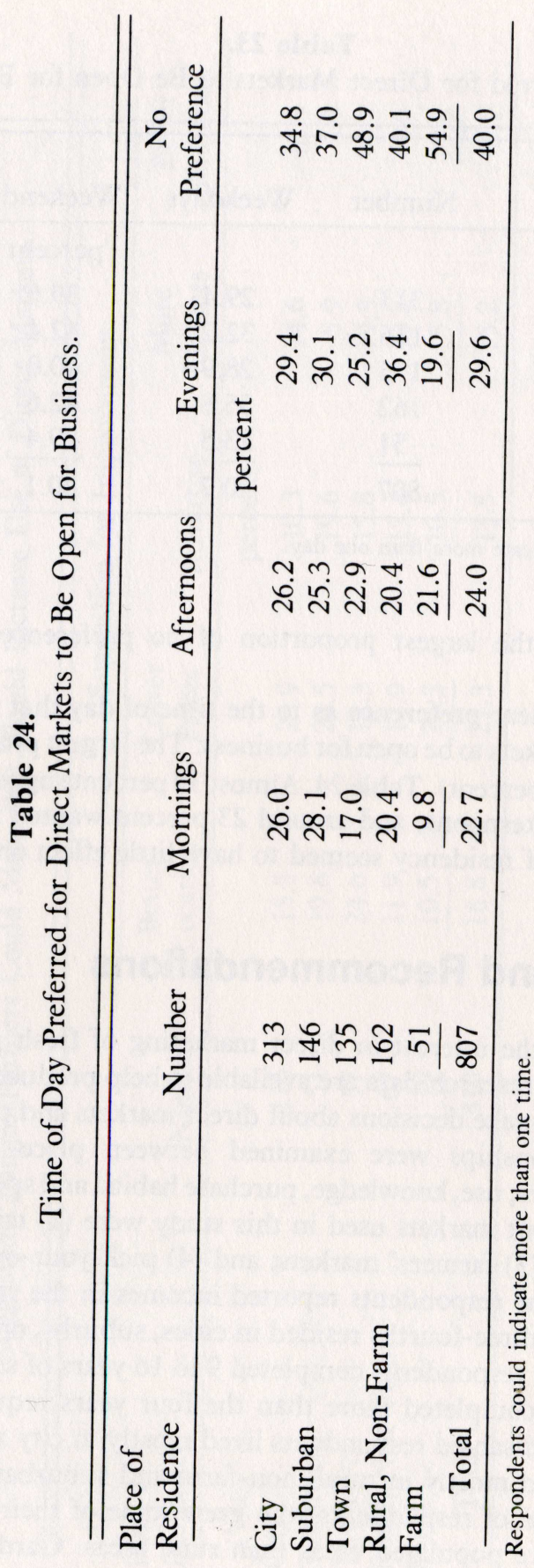

34 neighbors served as a source of produce for a lower percentage of rural residents than for residents in other areas. Home processing of fruits and vegetables was done by a much higher percentage of rural residents than residents of other areas.

In all places of residency most residents bought one to three different kinds of fruits and vegetables weekly. Almost twice as many respondents bought four to six kinds of vegetables weekly as did those who bought four to six kinds of fruits. Residents in rural areas purchased fewer fresh fruits and vegetables at retail stores. Almost half of the respondents purchased no fresh fruits or vegetables at direct markets. Most of the respondents who did purchase fresh produce at direct markets only purchased 10 percent or less of their total produce at these markets.

The largest proportion of respondents in all places of residency first learned about direct markets in their area by passing by them on the road. Farmers' markets were usually first learned about by word-of-mouth or advertisements and pick-your-own operations were usually first learned about by newspaper stories. Over a third of the respondents reported seeing or hearing advertisements for farmers' markets, and slightly more than 12 percent saw or heard ads for pick-your-own operations. Advertisements were seen or heard for tailgate markets and roadside stands by only 9 percent of the respondents.

The majority of respondents in each place of residency traveled five miles or

ess per round trip to a direct market, but 20 miles or more per round trip to pick-your-own operations.

More than half of the respondents in each place of residency judged the quality of fresh fruits and vegetables grown in West Virginia to be about the quality of state. Fewer rural farm residents than residents in same as that grown out of state. Fewer rural farm residents than grown elsewhere. The highest percentage (about 38 percent) of all respondents rated the quality of highest percentage (about 38 percent) of all respondents rated the only 5 percent rated grocery store quality as excellent. Almost 60 percent of the respondents thought produce purchased at direct markets was priced lower then produce purchased at grocery stores. More rural residents than others thought prices were lower at direct markets. Most respondents spent from $\$ 1$ to $\$ 50$ at direct markets in 1981. Rural farm residents generally spent less than others. Per visit expenditures ranged from $\$ 5$ to $\$ 9.99$ for over a third of the respondents. The highest expenditures per visit were at farmers' markets and pick-your-own operations. For all respondents, except farm residents, per weekly expenditure on fresh produce did not vary much between the growing season and the rest of the year. Most spent $\$ 10$ or less weekly.

Quality was regarded as the most important characteristic of fresh produce, with price second and appearance third. Reasons given for shopping at direct markets included quality, price, nice atmosphere, and convenience. The two 
most important reasons for nonuse or dislike were none nearby and
inconvenient.

Respondents listed changes that would increase their use of direct markets. These included lower prices, better locations, better sanitation, and more markets. Only a slightly higher percentage of respondents preferred weekend to weekdays as days of operations. There was also no great preference for time of day for the market to be open. Evenings were the most frequently listed, but only by a low percentage.

\section{Recommendations}

Rural residents generally make less use of direct markets as a source of fresh produce than residents of other areas. The main reason for this is that rural residents grow and preserve most of their fruits and vegetables. Respondents who lived in rural areas also generally had smaller incomes than those in the
cities, suburbs, or towns.

Direct markets could be used by rural residents as a way to increase their earnings. Extra fresh produce could be sold through direct markets. This would also benefit consumers because they would have more direct markets to shop at and a larger variety of fresh produce to choose from.

To help ensure a successful market there are several recommendations the producer should follow:

1. Be aware of any regulations that may apply to the market and also be sure to purchase any licenses that may be needed.

2. The locations of the market should be considered carefully. Some possible locations include near shopping centers, on regularly traveled commuter routes, and near recreation areas. The location should also have space for parking and easy entry and exit.

3. The produce should be clean, neat, and out of the sun, if possible. The vehicle or stand should also be clean and sanitary and the sellers should also be clean and neat.

4. Advertising should be used to let consumers know about the markets. Roadside signs, newspaper ads, and radio ads are three methods which can be used. They should let the consumer know what produce is available, prices, and hours open. 